\title{
APPLICATION OF ROWING ERGOMETERS IN PHYSICAL EDUCATION OF 11 TO 13-YEAR-OLD STUDENTS
}

\author{
Vihren Bachev, Orlin Groshev, Pavel Yordanov \& Boyan Zlatev \\ National Sports Academy „Vassil Levski”, Sofia, Bulgaria
}

\begin{abstract}
Introduction: Rowing is a sport with versatile functional impact, and it can be practiced in real and ergometers designed conditions. Although its advantages, rowing is still not applied in schools in Bulgaria. All these facts determine the necessity of defining a research problem.

Methodology: The aim of the research is an optimizing of the physical education for 11 to 13-year-old students, both boys and girls by applying rowing ergometers.

A poll has been made twice among 73 secondary school students $\left(5^{\text {th }}\right.$ and $6^{\text {th }}$ grade) in Bulgaria as well as an experiment consist of four tests including rowing ergometer at $300 \mathrm{~m}$. The registered results are: achievement (s), wattage (W), pulse rate (ppm) - before, immediately after, and 1 minute after completion of the test. Variation, correlation and alternative analyzes have been applied.

Results and analysis: A credible increase of pulse rate among the boys was registered: up to 18 to 114 beats per minute at rest and immediately after the test load during 300-meter of ergometer rowing training There is a favorable effect of the application of the simulator on the activity of the cardio respiratory system and a high correlation " $r$ " - $0.82, P t-0.95$, is observed between the wattage and the pulse rate immediately after the training.

Conclusion:

1. More than $80 \%$ of the 11-13-year-old students who took part in the research support the inclusion of rowing ergometers training in physical education program.

2. The application of rowing ergometers is possible and leads to a positive development of the functional capabilities.

3. Approved and age-matched ergometer tests are informative for controlling the physical condition of secondary school students in Bulgaria.
\end{abstract}

Key words: rowing ergometer, physical education, students

\section{INTRODUCTION}

Rowing is a multifactorial health sport practiced by individuals at any age in natural aquatic environments as well as modeling simulators. The most common of these are the Concept-2 rowing ergometers (Batchev, 2019; Hristov, 1998; Neikov, 2001, 2006, 2007, 2010, 2012; Gospoadrski, 2006, 2012, 2016; Stoyanova, 2016; Andonov, 2017).

The rowing ergometer is the most effective tool for training and modeling of target-specific training loads, and the achievements of different control tests, the achieved absolute and relative values of the wattage power provide specific and standard possibilities for individual assessments (Hagerman, 1972; Fraley, 1972; Gerdes, 1973; Maccenzy, 2011; Crouse, 1979).

The above-mentioned determines the widespread use of ergometers in the physical education process at both the Universities and the school physical education system. For Bulgaria, the process is in its inception phase.

The Stoyanova research -2016 with 40 students from the University of National and World Economy in Sofia aims to improve physical fitness by the application of dosed physical exercise with interval-variable ergometer. In this way, a new path has been created to optimize the learning process, making recommendations for the implementation and use of simulators for the unification, dosing and control of training effects as well as the development of models for the assessment of physical fitness in students.

Analyzes of educational programs in physical education for students in 5-8 grades in a Bulgarian secondary school revealed that water sports including "rowing" present as an additional core. The basis of lessons involving practicing rowing is the methodological axiom that the main means of developing motor skills is exercise. It should increase coordination complexity and to develop a sense of space, 
time and degree of neural muscular effort. Students improve their physical capacity, enrich their motor experience and learn the rowing boat's structure, the balance of their body on entry and exit, and basic controls needed for two paddles. Gender-differentiated content ensures that students with special educational needs are included in the training. The acquisition of theoretical knowledge is carried out in parallel with the mastery of motor tasks.

In this regard, we assumed that due to the difficult feasibility of rowing in the aquatic environment at school lessons, experimental results of simulated ergometer rowing would yield results useful for improving the physical education process.

\section{METHODOLOGY}

The aim of the study is experimentally determination of the effects on the perception of the facilities, the functional tolerance and the controllability of the dosed test loading by experimentally applying of rowing ergometers in physical education lessons for 11 to 13 years old students. On this basis, opportunities for optimizing the learning process are also foreseen. Objectives of the study

1. Analysis of the presence of rowing sport in the content of the curricula for physical education of 11 to 13 years old students at secondary schools.

2. Establishing the knowledge of 11-13-year-old students about rowing ergometers, their purpose and possibilities for introduction in the process of physical education.

3. Characteristics of functional tolerance in dosing loads of rowing ergometers in 11-13-year-old students.

4. Analysis of the possibilities for improving the fitness control of 11 to 13 years old students by including them in the accepted test battery and a control rowing ergometer test.

Object, subject areas, tested subjects

The object of study is to optimize the educational process of physical education in 11 to 13 years old students by applying rowing ergometers. Subject areas are physical education programs for 11 to 13 years old students from secondary schools in Bulgaria, applications of rowing ergometers such as facilities, ergometric functional impacts and tests to control physical fitness in students. Tested subjects - 11-12- and 13-years old students were included in the research. The tests investigated indicators and the number of subjects examined are summarized (Table 1).

Table 1. Tests, investigated indicators and students

\begin{tabular}{|l|c|c|c|c|c|}
\hline \multicolumn{1}{|c|}{ Tests } & $\begin{array}{c}\text { Rowing } \\
\text { ergometer test } \\
\text { (achievements; }\end{array}$ & $\begin{array}{c}\text { The standing } \\
\text { long jump } \\
\text { Examina- } \\
\text { tion } \\
\text { wattage power -w; } \\
\text { pulse rate - pcs; }\end{array}$ & $\begin{array}{c}\text { (achements- } \\
\text { s-cm) }\end{array}$ & $\begin{array}{c}\text { 50 m running } \\
\text { (achie- } \\
\text { vements-s) }\end{array}$ & $\begin{array}{c}\text { Running for } \\
\text { endurance } \\
\mathbf{3 0 0} \text { m- girls } \\
\mathbf{6 0 0 m} \text { - boys } \\
\text { (achievements-s) }\end{array}$ \\
\hline $\begin{array}{l}\mathbf{1 1 - 1 2} \text { years } \\
\text { old boys }\end{array}$ & 37 & 19 & 19 & 19 & 19 \\
\hline $\begin{array}{l}\mathbf{1 1 - 1 2} \text { years } \\
\text { old girls }\end{array}$ & 23 & 13 & 13 & 13 & 13 \\
\hline $\begin{array}{l}\mathbf{1 3} \text { years } \\
\text { old boys }\end{array}$ & 6 & 14 & 14 & 14 & 14 \\
\hline $\begin{array}{l}\mathbf{1 3} \text { years } \\
\text { old girls }\end{array}$ & 7 & 7 & 7 & 7 & 7 \\
\hline
\end{tabular}

Research methods: document analysis; observation; surveying - standardized survey, including 5 questions (1. do you know what a "rowing ergometer" is; 2. have you ever seen a "rowing ergometer"; 3 . do you know what a rowing ergometer is used for; 4 . do you want to use a rowing ergometer; 5. do you think "rowing ergometers" can be used in physical education classes) with 3 possible answers-"yes"; "no"; "I'm not sure", was conducted twice among 73 students; experimental tests- 4 tests were conducted (Table 1) with thirty two 11 to 12 year old and twenty one 13 year old students from 5-6 grades. The rowing ergometer test was expertly determined to be $300 \mathrm{~m}$ long, with the argument that it was the same for the endurance running test and for a load duration of 80-100 s; palpation by the teacher in 
each subject was measured pulse rate before (HR (Kaytsanov, 2009).

1 ), immediately after (HR 2), and 1 minutes after the loading (HR 3); mathematical-statistical methods-alternative; variational; correlation analyzes; comparative theoretical analysis and synthesis.

\section{OBTAINED RESULTS}

The large volume of the received data does not allow their full presentation. We focus on integrative All the above-mentioned studies were conducted in the period 01.04.-01.06. 2018 with students in 5-6 grades from 21st Secondary School in Sofia, using 2 rowing ergometers of type "Concept II" and active assistance of the teachers in physical education.

examples. Results of variational analysis of performance data, wattage power and pulse rate changes in the rowing ergometer test are systematized (Tables 2 to 5$)$.

Table 2. Variability of results in all tested 11 to 12 years old boys $(n=19)$

\begin{tabular}{|l|l|l|l|l|l|l|l|l|}
\hline \multicolumn{1}{|c|}{ Indicators } & & Time & Loading & HR 1 & HR 2 & HR 3 & HR 2 - HR 1 & $\begin{array}{c}\text { HR 2 - HR } \\
\text { 3 }\end{array}$ \\
\hline Mean & 11,89 & 82,22 & 138,56 & 89,47 & 152,53 & 86,74 & 63,05 & 65,79 \\
\hline $\begin{array}{l}\text { S t a n d a r d } \\
\text { Deviation }\end{array}$ & 0,32 & 12,34 & 43,48 & 18,40 & 32,46 & 19,03 & 25,10 & 23,05 \\
\hline Kurtosis & 6,51 & 0,57 & $-1,48$ & $-0,43$ & $-0,05$ & $-0,61$ & $-0,32$ & 0,27 \\
\hline Skewness & $-2,80$ & 0,55 & $-0,06$ & $-0,59$ & $-0,76$ & 0,43 & 0,21 & $-1,00$ \\
\hline Range & 1,00 & 47,00 & 132,00 & 60,00 & 120,00 & 60,00 & 96,00 & 78,00 \\
\hline Minimum & 11,00 & 61,00 & 69,00 & 54,00 & 84,00 & 60,00 & 18,00 & 18,00 \\
\hline Maximum & 12,00 & 108,00 & 201,00 & 114,00 & 204,00 & 120,00 & 114,00 & 96,00 \\
\hline
\end{tabular}

Table 3. Variability of results in tested 11 to 12 years old boys without the 4 best and worst achievements $(n=15)$

\begin{tabular}{|l|l|l|l|l|l|l|l|l|}
\hline \multicolumn{1}{|c|}{ Indicators } & Years & Time & Loading & HR 1 & HR 2 & HR 3 & HR 2 - HR 1 & HR 2 - HR 3 \\
\hline Mean & 11,93 & 82,07 & 136,40 & 89,20 & 147,60 & 82,80 & 58,40 & 64,80 \\
\hline $\begin{array}{l}\text { S t a n d a r d } \\
\text { Deviation }\end{array}$ & 0,26 & 6,85 & 38,20 & 20,52 & 32,22 & 17,15 & 22,39 & 25,48 \\
\hline Kurtosis & 15,00 & $-1,10$ & $-1,51$ & $-0,95$ & $-0,40$ & $-0,06$ & $-0,67$ & $-0,35$ \\
\hline Skewness & $-3,87$ & $-0,23$ & 0,20 & $-0,54$ & $-0,89$ & 0,51 & $-0,15$ & $-0,87$ \\
\hline Range & 1,00 & 22,00 & 118,00 & 60,00 & 102,00 & 60,00 & 78,00 & 78,00 \\
\hline Minimum & 11,00 & 70,00 & 83,00 & 54,00 & 84,00 & 60,00 & 18,00 & 18,00 \\
\hline Maximum & 12,00 & 92,00 & 201,00 & 114,00 & 186,00 & 120,00 & 96,00 & 96,00 \\
\hline
\end{tabular}

Table 4. Variability of results in all tested 11 to 12 years old girls $(n=13)$

\begin{tabular}{|l|l|l|l|l|l|l|l|l|}
\hline Indicators & Years & Time & Loading & HR 1 & HR 2 & HR 3 & HR 2 - HR 1 & HR 2 - HR 3 \\
\hline Mean & 11,62 & 97,69 & 94,38 & 78,46 & 138,46 & 77,08 & 56,77 & 57,54 \\
\hline $\begin{array}{l}\text { S t a n d a r d } \\
\text { Deviation }\end{array}$ & 0,51 & 10,75 & 29,20 & 14,17 & 29,54 & 17,81 & 18,43 & 22,11 \\
\hline Kurtosis & $-2,06$ & $-1,24$ & $-1,29$ & $-1,18$ & $-0,93$ & $-0,04$ & $-0,10$ & $-0,75$ \\
\hline Skewness & $-0,54$ & $-0,09$ & 0,44 & 0,21 & $-0,55$ & 0,70 & $-0,29$ & $-0,34$ \\
\hline Range & 1,00 & 33,00 & 80,00 & 42,00 & 90,00 & 60,00 & 66,00 & 72,00 \\
\hline Minimum & 11,00 & 82,00 & 59,00 & 60,00 & 90,00 & 54,00 & 24,00 & 18,00 \\
\hline Maximum & 12,00 & 115,00 & 139,00 & 102,00 & 180,00 & 114,00 & 90,00 & 90,00 \\
\hline
\end{tabular}


Table 5. Variability of results in tested 11 to 12 years old girls without the 2 best and worst achievements $(n=11)$

\begin{tabular}{|l|l|l|l|l|l|l|l|l|}
\hline Indicators & Years & Time & Loading & HR 1 & HR 2 & HR 3 & HR 2 - HR 1 & HR 2 - HR 3 \\
\hline Mean & 11,55 & 97,55 & 93,09 & 76,36 & 134,73 & 75,27 & 54,55 & 54,91 \\
\hline $\begin{array}{l}\text { S t a n d a r d } \\
\text { Deviation }\end{array}$ & 0,52 & 9,17 & 27,02 & 14,22 & 30,52 & 18,85 & 19,25 & 23,02 \\
\hline Kurtosis & $-2,44$ & $-1,34$ & $-0,92$ & $-0,74$ & $-1,21$ & 0,39 & $-0,10$ & $-0,86$ \\
\hline Skewness & $-0,21$ & $-0,33$ & 0,49 & 0,56 & $-0,29$ & 1,03 & 0,03 & $-0,04$ \\
\hline Range & 1,00 & 25,00 & 80,00 & 42,00 & 90,00 & 60,00 & 66,00 & 72,00 \\
\hline Minimum & 11,00 & 84,00 & 59,00 & 60,00 & 90,00 & 54,00 & 24,00 & 18,00 \\
\hline Maximum & 12,00 & 109,00 & 139,00 & 102,00 & 180,00 & 114,00 & 90,00 & 90,00 \\
\hline
\end{tabular}

\section{RESULTS}

The analysis of the results of the survey shows that the 11 to 13-year old included in the surveys for the most part - more than $80 \%$ have no clear knowledge of the rowing ergometer simulator before being shown by the teacher and practically in the second survey, knowledge changed diametrically in a positive direction.

The answers to question № 3 "Do you know what a rowing ergometer is used for" have similar quantitative content and also undergo significant positive changes in the second survey.

The summary of the opinions of the students tested by us about the possible use of rowing ergometers in the physical education teaching process (Figure 1) shows that after acquaintance with the facility more than $90 \%$ of them approve this possibility.

Analyzes of changes in pulse rate during the ergometer test show a logical increase for all tested students with expected individual differences. In the group of 11 to 12 years old boys (Table 2) the values are in a very wide range as a result of the loading - from 84 to 204 beats per minute. When the best and worst achievements of the subjects are reduced (Table 3), these values change from 84 to 186 beats per minute, respectively. In the surveyed 11 to 12 years old girls (Tables 4 and 5) the quantitative changes are from a minimum of 90 to a maximum of 180 beats per minute. When the data is added to thus observed cases, and for the 13-year-old boys, changes were observed from a minimum of 114 to a maximum of 192 and 196 beats per minute.

During the analysis of the values of achievements and achieved power it is evident from the data that for 11 to 12 years old boys (Table 3 ) they are in the range of 70-92 sec. and the power is -83 to 201 watts. For girls, the range of achievements is 84 to 109 seconds, and the power is -59 to 103 watts. For 13 -year-old boys, the values change for the achi- evements from 68 to 90 seconds, and the power is from 104 to 237 watts.

We reach to the conclusion that the applied ergometer loads are functionally bearable by the tested subjects and do not lead to overload, fatigue or undesirable changes. It can be predicted that positive effects on the activity of their cardiorespiratory system will be expected when such effects are systematically applied.

The facts established by us methodologically correspond with the results obtained by S. Stoyanova -2016 in non-sporting students. The applied sixmonth pedagogical impact with a specialized ergometer program improves the capacity and functional capacity of the subjects.

The analysis of the possibilities of application of rowing ergometers and in the process of control of physical fitness for the tested students are based on the values of the isolated correlation coefficients. It was found for the rowing test example that the results strongly correlate with achieved wattage power ( $r=-0,931$ for boys and $r=-0,857$ for girls) The obtained results are logical and confirmatory, since many positive responses have been made on the basis of these guidelines.

More informative about the control process are the analyzes related to the values of correlation coefficients between the indicators measured in the rowing ergometer test and the results of the other 3 control tests applied, since it is known that physical fitness tests for students of $5^{\text {th }}$ and $6^{\text {th }}$ grade of Secondary schools are combined into a heterogeneous battery and measure the states of individual motor skills (Rachev, 1998; Nikolova, 2012; Damyanova, 2012).

Between the achievement of the ergometer test and the results of the jump test, the correlation coefficients are $r=0.430$ for boys and $r=0.199$, respectively. For the $50 \mathrm{~m}$ smooth running test, the values are $r=-0.492$ for boys and $r=0.319$ for girls. Sep- 
arate dependencies are contradictory, but give reason to support, especially in the group of girls, that the tests measure independent indicators.

Correlation coefficients between the endurance measuring two tests - $300 \mathrm{~m}$ ergometer rowing and athletic running at the same distance are $r=-0,233$ for boys and $r=-0,133$ for girls. Analyzes show that an experiment of this type is not informative about the control process. It is necessary to conduct a series of new targeted studies to allow selection of a control test loading adequate for this age group.

\section{CONCLUSIONS}

1. It was found that rowing sport is present in the content of the curriculum in physical education for 11 to 13-year-old students in the secondary schools in Bulgaria. The rowing practice is difficult in real terms, but the practice of modeled rowing ergometry is possible prognostic.

2. The tested Bulgarian 11 to 13 years old students have no initial knowledge of rowing ergometers and their purpose, but after initial acquaintance they positively evaluate the possibilities for their introduction in the process of physical education.

3. Analyzes of changes in indicators for dosing loads of rowing ergometers show the functional tolerance of 11-13-year-old students to their application.

4. There are principle opportunities to improve the fitness control of 11-13-year-old students by including them in a test battery and a test ergometer, but with a different length from the experimented $300 \mathrm{~m}$.

5. There are positive opportunities to optimize the process of physical education in Bulgarian secondary school by applications and rowing ergometers.

\section{REFERENCES}

Andonov, H. (2017). Prilozhni aspekti na trenirovkata na elitni grebtsi (monografia) Bolid-Ins, Sofia, ISBN 978954-394-211-4.

Astrand P., Rodahl K. (1986). Textbook of work physiology (Physiological bases of exercise 3-th Edition)- Printed in U.S.A.; Mc Craw-Hill, Inc.

Bachev, V. (2019). Kontrol na fizicheskata podgotovka $v$ grebaneto, NSA-Pres, Sofia, ISBN 978-954-718-585-2.

Gerdes, R. (1973). Mahovik sas spirachno ustroystvo greben ergometar, K.N.P.D., 21, Sofia

Gospodarski, N. (2012) Izsledvane na funktsionalnite promeni $\mathrm{v}$ organizma pri izpalnenieto na maksimalen test na 2000m greben ergometar" - Mezhdunarodna nauchna konferentsia „Sport, Stres, Adaptatsia”, Sofia. Gospodarski, N. (2006). Savremenni vazmozhnosti za upravlenie na trenirovachnia protses po grebane s pomoshtta na "Concept 2 PM3" - Nauchna konferentsia na kat. „Vodni sportove, Sofia

Damyanova, R. (2012). Teoretichni osnovi na testovoto izmervane $i$ otsenyavane vav fizicheskoto vazpitanie $i$ sporta, NSA-Pres, Sofia. ISBN 978-954-718-309-4.

Eurofit. (1993). Eurofit Tests of Physical Fitness, 2nd Edition, Strasbourg.

Ferriss, Y. (1992). Rowing Fundamentals-the coaching resourse, Ithaca,New York, U.S.A.

Freyli, D. (1972). Stoynostta na grebnite ergometri, Rushershport, Minden, 4.

Fomin N., V. Filin - (1975) - Vazrastovi osobenosti na fizicheskoto vazpitanie, Meditsina i fizkultura, Sofia.

Hagerman, F. (1972). Izpolzvane na podbornite parametri pri komplektovane na novozelandskata osmorka, Rushershport, Minden, 48.

Hristov, R. (1998). Usavarshenstvane na biomehanichnata struktura na dvigatelnite deystvia pri visokorazryadni sportisti v grebaneto, Diss, NSA, Sofia.

Krauze, D. (1979). Vazmozhnosti za funktsionalna otsenka na aerobnia kapatsitet pri grebtsi chrez greben ergometar, Rudershport, 33.

Kulmey, B. (1974). Greben ergometar, Rudershport, 33. Kaytsanov, P. (2019). Prilozhenia na grebnite ergometri v protsesa na fizichesko vazpitanie $v$ uchilishte (uchenitsi 5-6 ti klas na SU na Bulgaria,) Bachelor thesis, NSA,Sofia.

Makkenzi, B. (2011). 101 testa za otsenka na fizicheskata godnost, Bins, Sofia.

Mathews, D. (1973). Measurements in physical education. Philadelphia, Saunders.

Neykov, S. (2012). Postroyavane i upravlenie na sportnata trenirovka na elitni sastezateli po grebane, Bold Ins, Sofia. Neykov, S. (2010). Kontrol na natovarvaneto i na spetsifichnata raboto $\neg$ sposob-nost pri elitni sastezateli po grebane, Sport i nauka, 6, pp. 3-19.

Neykov, S. (2007). Trenirovka na elitni grebtsi v godishnia tsikal, monografia, Tip-Top-Pres, Sofia, ISBN 978-954723-015-6.

Nikolova, E. (2012). Dvigatelnite kachestva v uchebnata programa po fizichesko vazpitanie, Bolid Ins, Sofia.

Rachev, K. (1998). Teoria i metodika na fizicheskoto vazpitanie - obshti osnovi,teoria i metodika na fizicheskoto vazpitanie, NSA-Pres, Sofia.

Stoyanova, S. (2016). Razvivane na fizicheskata godnost na studenti ot UNSS chrez konditsionna podgotovka na greben ergometar, Diss, NSA, Sofia.

Zhelyazkov, Ts., Dasheva, D. (2017). Osnovi na sportnata trenirovka, Bolit Ins., Sofia.

http//www.mon.bg.

http//www.topendsports.com/testing/tests/hexagon. htm

Corresponding autor:

Prof. Vihren Bachev, DSc,

National Sports Academy "Vassil Levski", 1700 Sofia, Bulgaria

E-mail: batchevv@yahoo.com 